\title{
TRIM16 wt Allele
}

National Cancer Institute

\section{Source}

National Cancer Institute. TRIM16 wt Allele. NCI Thesaurus. Code C106034.

Human TRIM16 wild-type allele is located in the vicinity of 17p11.2 and is approximately $56 \mathrm{~kb}$ in length. This allele, which encodes tripartite motif-containing protein 16 , plays a role in retinoic acid signaling, histone acetylation and keratinocyte differentiation. 